\title{
Correction to: Sensitivity Analysis for Not-at-Random Missing Data in Trial-Based Cost-Effectiveness Analysis: A Tutorial
}

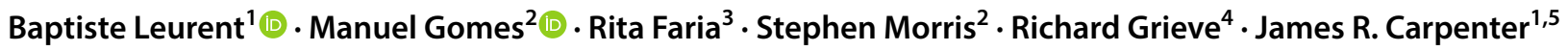

Published online: 9 March 2019

(c) The Author(s) 2019

\section{Correction to: PharmacoEconomics (2018) 36:889-901 https://doi.org/10.1007/s40273-018-0650-5}

The Open Access license, which previously read:

Open Access This article is distributed under the terms of the Creative Commons Attribution-NonCommercial 4.0International License (http://creativecommons.org/licen ses/by-nc/4.0/), which permits any noncommercial use, distribution, and reproduction in any medium, provided you give appropriate credit to the original author(s) and the source, provide a link to the Creative Commons license, and indicate if changes were made.

Should read:
Open Access This article is distributed under the terms of the Creative Commons Attribution 4.0 International License (http://creativecommons.org/licenses/by/4.0/), which permits unrestricted use, distribution, and reproduction in any medium, provided you give appropriate credit to the original author(s) and the source, provide a link to the Creative Commons license, and indicate if changes were made.

The original article was corrected.

Open Access This article is distributed under the terms of the Creative Commons Attribution 4.0 International License (http://creativeco mmons.org/licenses/by/4.0/), which permits unrestricted use, distribution, and reproduction in any medium, provided you give appropriate credit to the original author(s) and the source, provide a link to the Creative Commons license, and indicate if changes were made.
The original article can be found online at https://doi.org/10.1007/ s40273-018-0650-5.

\section{Baptiste Leurent}

baptiste.leurent@1shtm.ac.uk

1 Department of Medical Statistics, London School of Hygiene and Tropical Medicine, Keppel Street, London WC1E 7HT, UK

2 Department of Applied Health Research, University College London, London, UK

3 Centre for Health Economics, University of York, York, UK

4 Department of Health Services Research and Policy, London School of Hygiene and Tropical Medicine, London, UK

5 MRC Clinical Trials Unit at University College London, London, UK 